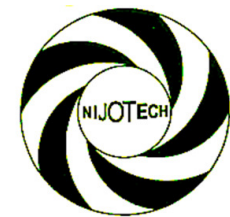

Nigerian Journal of Technology (NIJOTECH)

Vol. 35, No. 1, January 2016, pp. $190-195$

Copyright@ Faculty of Engineering, University of Nigeria, Nsukka,

Print ISSN: 0331-8443, Electronic ISSN: 2467-8821

www.nijotech.com

\title{
DETERMINATION OF HEAD FOR SMALL HYDROPOWER DEVELOPMENT: A CASE STUDY OF RIVER ETHIOPE AT UMUTU
}

\author{
S. O. Otuagoma ${ }^{1}$, E. A. Ogujor ${ }^{2}$ and P. A. Kuale ${ }^{3}$

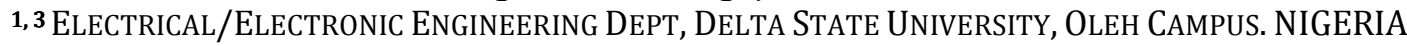 \\ 2 ELECTRICAL/ELECTRONIC ENGINEERING DEPT, UNIVERSITY oF BENIN, BENIN City. NIGERIA \\ E-mailaddresses:1 otuagoma@yahoo.com, ${ }^{2}$ emma.ogujor@uniben.edu, ${ }^{3}$ paokuale@yahoo.com
}

\begin{abstract}
In this study, an appropriate head in metre for small hydropower development for the River Ethiope at the source at Umutu was determined. The Dumpy levels and Theodolite method were used to determine the head at the source at Umutu. The results showed that the gross head of the River Ethiope at Umutu is roughly $18.5 \mathrm{~m}$ using the Dumpy levels and Theodolite method. However, in every hydraulic structure, there are losses. The head loss was calculated to be $9.3 \mathrm{~m}$ thereby placing the net head to be $9.2 \mathrm{~m}$ using value from the Dumpy levels. With a head of $9.2 \mathrm{~m}$ and a volumetric flow of $31.73 \mathrm{~m}^{3} / \mathrm{s}$, the power potential of the River Ethiope was placed at $2.43 \mathrm{MW}$. It can therefore be concluded that the River Ethiope when fully harnessed could generate electricity to meet part of the power need of the Delta State University, Abraka and the surrounding communities.
\end{abstract}

Keywords: small hydropower, gross head, net head, volumetric flow, river profile, hydraulic power.

\section{INTRODUCTION}

In every hydropower development, the two important parameters that help to determine available hydraulic power inherent in the system are the volumetric flow and the available head. There are well defined methods for measuring these parameters. In this study however, the focus will be on the measurement of available head of River Ethiope at the source at umutu. The available head is defined as the vertical distance that water falls [1]. Figure 1 shows the head as the vertical distance water falls.

This head is also a function of the characteristics of the channel or pipe through which the water flows. It is generally better to have more head than more

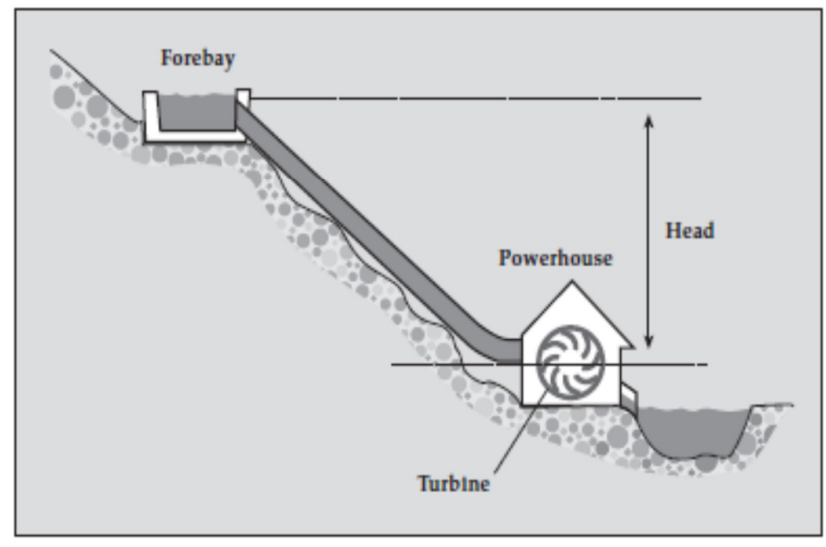

Figure 1. Head is the vertical distance water falls volumetric flow; because less water will be needed to produce a given amount of power with smaller, less expensive equipment [2].

The River Ethiope which is situated in the north central part of Delta State lies between latitudes $5^{0} 40^{\prime} 6^{\prime \prime} \mathrm{N}$ and $6^{0} 00^{\prime} \mathrm{N}$ and longitudes $5^{0} 39^{\prime} 5^{\prime \prime} \mathrm{E}$ and $6^{0} 10^{\prime} 9^{\prime \prime} \mathrm{E}$ as presented in Figure 2 [3]. It is located within the equatorial region with two climatic conditions - the wet and dry seasons [4]. The River Ethiope's volumetric flow has been investigated by Otuagoma et al [4] and the economic potentials of the river have also been reported on by Adiotomre et al [5].

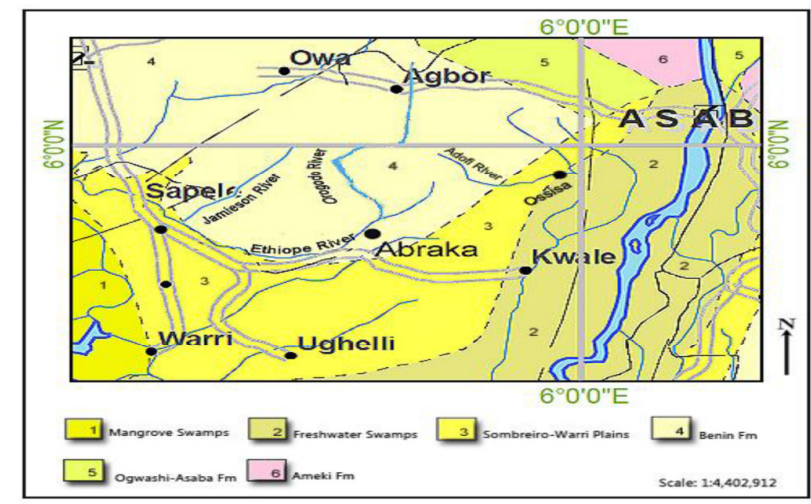

Figure 2. Geological Map of Part of Western Niger Delta Showing the location of Ethiope River [3]. 
However, no much work has been done at Umutu to ascertain how high the head could possibly be for all water projects such as water supply, irrigation and small hydropower development. This study therefore focuses attention on head measurement at the source and to ascertain inherent losses to determine the net head available for small hydropower development.

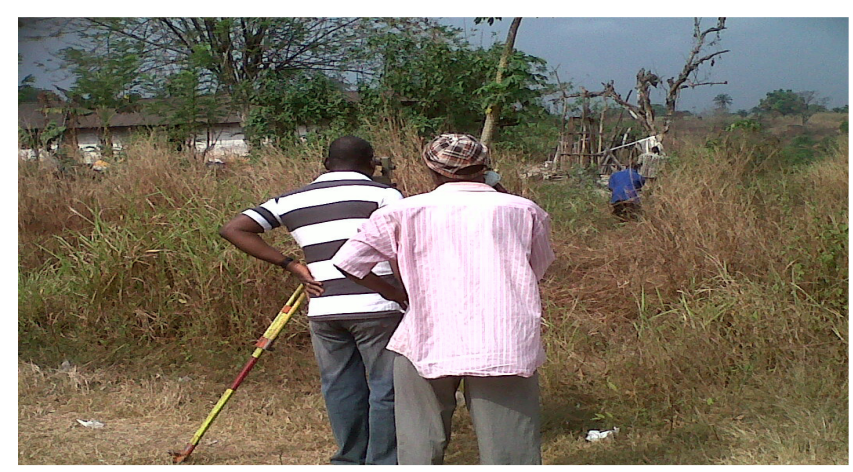

Figure 3. Head Measurement Technique

\section{MATERIALS AND METHODS}

In this study, head measurements were carried out involving the measurement of horizontal and vertical distances at the source at Umutu and from which the river profile was drawn. The Dumpy levels and Theodolite method were used to determine the head of the River Ethiope.

\subsection{Dumpy Levels and Theodolite}

The use of dumpy levels (or builder's level) is the conventional method for measuring head. This equipment was used by an experienced surveyor who was capable of checking the calibration of the device. Dumpy levels were used with staffs to measure head in a series of stages. A dumpy level is a device which allows the operator to take sight on a staff held by a colleague, knowing that the line of sight is exactly horizontal. Stages were usually limited by the length of the staff to a height change of not more than $3 \mathrm{~m}$. A clear unobstructed view was needed; this requires clearing the site before measurements were taken. Dumpy levels only allow a horizontal sight but theodolite can also measure vertical and horizontal angles, giving greater versatility and allowing faster work. Figure 3 shows how this method was employed in this study.

\section{PRESENTATION OF RESULT / DISCUSSIONS}

\subsection{Head Measurement with Dumpy levels and} Theodolite

The gross head of a water resource is defined as the absolute vertical distance between the points of entry of the intake system to the point at which the water imparts onto the turbine. It was illustratively depicted in Figure 1. The net head is defined as the gross head minus all pipe losses due to friction and turbulence and is used to calculate the available power capacity of the water resource.

To determine the net head, the river's gross head must be measured and pipe loses calculated. The pipe losses are calculated using the dimensions and characteristics of the penstock. The gross head was measured at the lake using the Surveyor's method. In this method, the line of sight was first of all cleared of any obstruction. Next, the Dumpy levels and Theodolite was set up at each measurement point on a horizontal reference point and at an appropriate distance, assistant holds the staff vertically. The experienced surveyor now reads off and records both the horizontal distances and the vertical incremental elevation. The equipment was then moved to the point where the assistant was standing and the process was repeated until the whole area was surveyed. This method was illustratively depicted in Figure 3.

The data collected for the horizontal and vertical distances measured at the lake were recorded in the Table 1, and a plot of the lake profile is represented in Figure 4. From the lake profile, gross head of $18.5 \mathrm{~m}$ can be estimated.

\subsection{Head Losses in the Penstock}

The average volumetric flow rate of the River Ethiope was $31.73 \mathrm{~m}^{3} / \mathrm{s}$ [4]. For optimum performance, the penstock will be straight and steep as practical and has a continuous down-ward gradient. A penstock with an internal diameter of $48^{\prime \prime}(1.2192 \mathrm{~m})$ and a length of $45 \mathrm{~m}$ will be used in this design. The reason is that for a given flow rate, as the pipe diameter change between laminar and turbulent flow, the velocity of the water must increase, and the corresponding energy loss increases. This occurs because velocity is a function of friction. As velocity increases, friction increases. On the other hand, a large pipe diameter would mean a decrease in velocity and a corresponding decrease in friction (head loss). The cost of the pipe however, increases drastically with the increase in diameter. An important parameter used to predict and estimate the type of fluid flow in a pipe is the Reynold's number. It is a ratio that defines the relationship between inertial forces to viscous forces of a fluid. This number not only helps predict the type of fluid flow exhibited but will determine at what point the fluid might change between laminar and turbulent flow.

The equation for Reynolds' number for generalised fluid flow in a closed circular pipe is defined as [6].

$$
R_{e}=\frac{\rho V D}{\mu}=\frac{V D}{\gamma}
$$

In (1), $\rho$ is the density of the fluid $\left(\mathrm{Kg} / \mathrm{m}^{3}\right), \gamma$ is the average (mean) fluid velocity (m/s), D is the inner diameter of the penstock $(\mathrm{m}), \mu$ is the dynamic viscosity of the fluid $(\mathrm{Kg} / \mathrm{m}-\mathrm{s}), \mathrm{v}$ is the kinematic viscosity of the fluid $\left(\mathrm{m}^{2} / \mathrm{s}\right)$ 
The average fluid flow velocity is calculated as:

$$
V=\frac{Q}{A}=\frac{31.73}{\pi\left(\frac{1.2192}{2}\right)^{2}}=27.179 \mathrm{~m} / \mathrm{s}
$$

The kinematic and dynamic water viscosity coefficients used to calculate the Reynolds' number are listed in the Table 2 for varying ambient temperatures.

Table 1. Measurement of Horizontal and Vertical Distances of the Lake, Umutu, January, 2012.

\begin{tabular}{|c|c|c|c|c|c|c|c|c|c|c|c|c|}
\hline \multicolumn{5}{|c|}{ Surveyors and consultants } & \multirow{2}{*}{\multicolumn{4}{|c|}{ LEVELING }} & & & & \\
\hline \multicolumn{5}{|c|}{ D. Ugbekile } & & & & & \multicolumn{3}{|l|}{ Instr. } & Instr. \\
\hline & & & & & & & & & \multicolumn{4}{|c|}{ Area: Mission Rd, Umatu } \\
\hline \multirow{2}{*}{$\begin{array}{l}\text { Station } \\
\text { No }\end{array}$} & \multirow{2}{*}{$\begin{array}{l}\text { Staff } \\
\text { Set-up }\end{array}$} & \multicolumn{2}{|c|}{ Direction } & \multirow[t]{2}{*}{ Distance } & \multicolumn{3}{|c|}{ Staff Reading } & \multirow[t]{2}{*}{ Diff. Elav } & \multirow{2}{*}{$\begin{array}{l}\text { Prov. } \\
\text { Elav. }\end{array}$} & \multirow[t]{2}{*}{ Corr. } & \multirow{2}{*}{$\begin{array}{l}\text { Adjusted } \\
\text { Elav. }\end{array}$} & \multirow[t]{2}{*}{ Remark } \\
\hline & & 0 & I & & Dack & Interm & Fore & & & & & \\
\hline TBMI & Top & & & & 191 & & & & & & 100.000 & $\begin{array}{l}\text { Assumed } \\
\text { Datum }\end{array}$ \\
\hline CRDAM & & & & & & 1243 & & & & & 99.95 & \\
\hline PIERM & G.L & & & & & 1587 & & & & & 99.60 & \\
\hline \multirow[t]{31}{*}{$\checkmark$} & TOP & & & & 0.847 & & 1.563 & & 99.628 & 6.004 & 99.632 & \\
\hline & & & & & & 1.384 & & & & & 99.10 & \\
\hline & & & & & & 2.349 & & & & & 98.13 & \\
\hline & & & & & & 3.242 & & & & & 97.24 & \\
\hline & & & & & & 4.426 & & & & & 96.05 & \\
\hline & & & & & 0.397 & & 4.541 & & 95.934 & $0+.008$ & 95.76 & \\
\hline & & & & & & 2.578 & & & & & 92.531 & \\
\hline & & & & & 0.772 & & 3.812 & & 92.519 & $0+.012$ & 92.19 & \\
\hline & & & & & & 1.114 & & & & & 89.97 & \\
\hline & & & & & & 3.330 & & & & & 88.45 & \\
\hline & & & & & 0.782 & & 4.852 & 88.439 & & $0+.016$ & 88.16 & \\
\hline & & & & & & 1.076 & & & & & 86.67 & \\
\hline & & & & & & 2.566 & & & & & 85.95 & \\
\hline & & & & & & 3.288 & & & & & 84.920 & \\
\hline & & & & & 0.258 & & 4.321 & 84.900 & & $0+.020$ & 84.16 & \\
\hline & & & & & & 1.017 & & & & & 83.63 & \\
\hline & & & & & & 1.547 & & & & & 83.35 & \\
\hline & & & & & & 1.827 & & & & & 83.739 & \\
\hline & & & & & 1.280 & & 1.443 & 83.715 & & $0+.024$ & 81.89 & $\begin{array}{l}\text { Bottom } \\
\text { of Rive }\end{array}$ \\
\hline & & & & & & 3.129 & & & & & 83.15 & $\begin{array}{l}\text { Top of } \\
\text { River }\end{array}$ \\
\hline & & & & & & 1.867 & & & & & & \\
\hline & & & & & & & & & & & 84.260 & \\
\hline & & & & & 2.028 & & 0.763 & 84.232 & & $0+.028$ & 83.45 & \\
\hline & & & & & & 2.838 & & & & & 85.385 & \\
\hline & & & & & 3.348 & & 0.907 & 85.353 & & $0+.028$ & 86.35 & \\
\hline & & & & & & 2.382 & & & & & 87.72 & \\
\hline & & & & & & 1.009 & & & & & 88.610 & \\
\hline & & & & & 3.937 & & 0.127 & 88.574 & & $0+036$ & 91.89 & \\
\hline & & & & & & 0.659 & & & & & 92.403 & \\
\hline & & & & & 3.344 & & 0.148 & 92.363 & 95.403 & $0+.040$ & 93.66 & \\
\hline & & & & & & 2.084 & & & & & 94.06 & $\begin{array}{l}\text { Edge } \\
\text { borrow }\end{array}$ \\
\hline Top & & & & & & 1.683 & & & & & 92.19 & $\begin{array}{l}\text { Borrow } \\
\text { pit }\end{array}$ \\
\hline & & & & & & 3.555 & & & & & 92.33 & \\
\hline & +16 & & & & & 3.420 & & & & & 95.483 & $\begin{array}{l}\text { Borrow } \\
\text { pot }\end{array}$ \\
\hline & & & & & 3.368 & & 0.268 & 95.439 & 98.479 & $0+.044$ & 97.19 & $\begin{array}{l}\text { Edge } \\
\text { borrow } \\
\text { pit }\end{array}$ \\
\hline & & & & & & 1.660 & & & & & 97 & \\
\hline & & & & & & & & & & & 97.57 & \\
\hline & & & & & & 1.280 & & & & & 98.42 & \\
\hline & & & & & & 0.433 & & & & & 98.488 & \\
\hline & & & & & 2660 & & 0.367 & 98.440 & 101.480 & $0+.048$ & 98.61 & \\
\hline & & & & & & 2.542 & & & & & 99.23 & \\
\hline & & & & & & 1.920 & & & & & 99.46 & \\
\hline & & & & & & 1.684 & & & & & & \\
\hline
\end{tabular}


Table 1. Measurement of Horizontal and Vertical Distances of the Lake (continued).

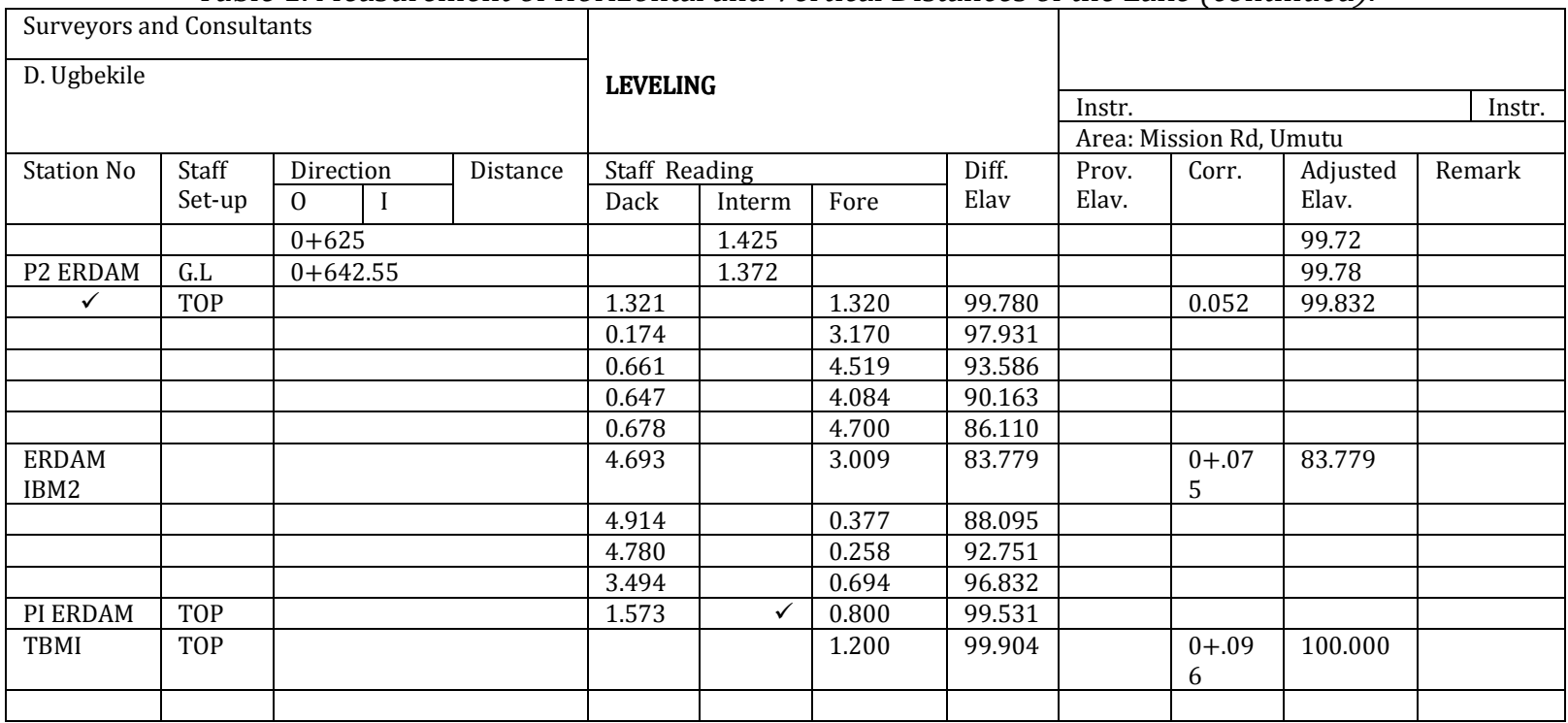

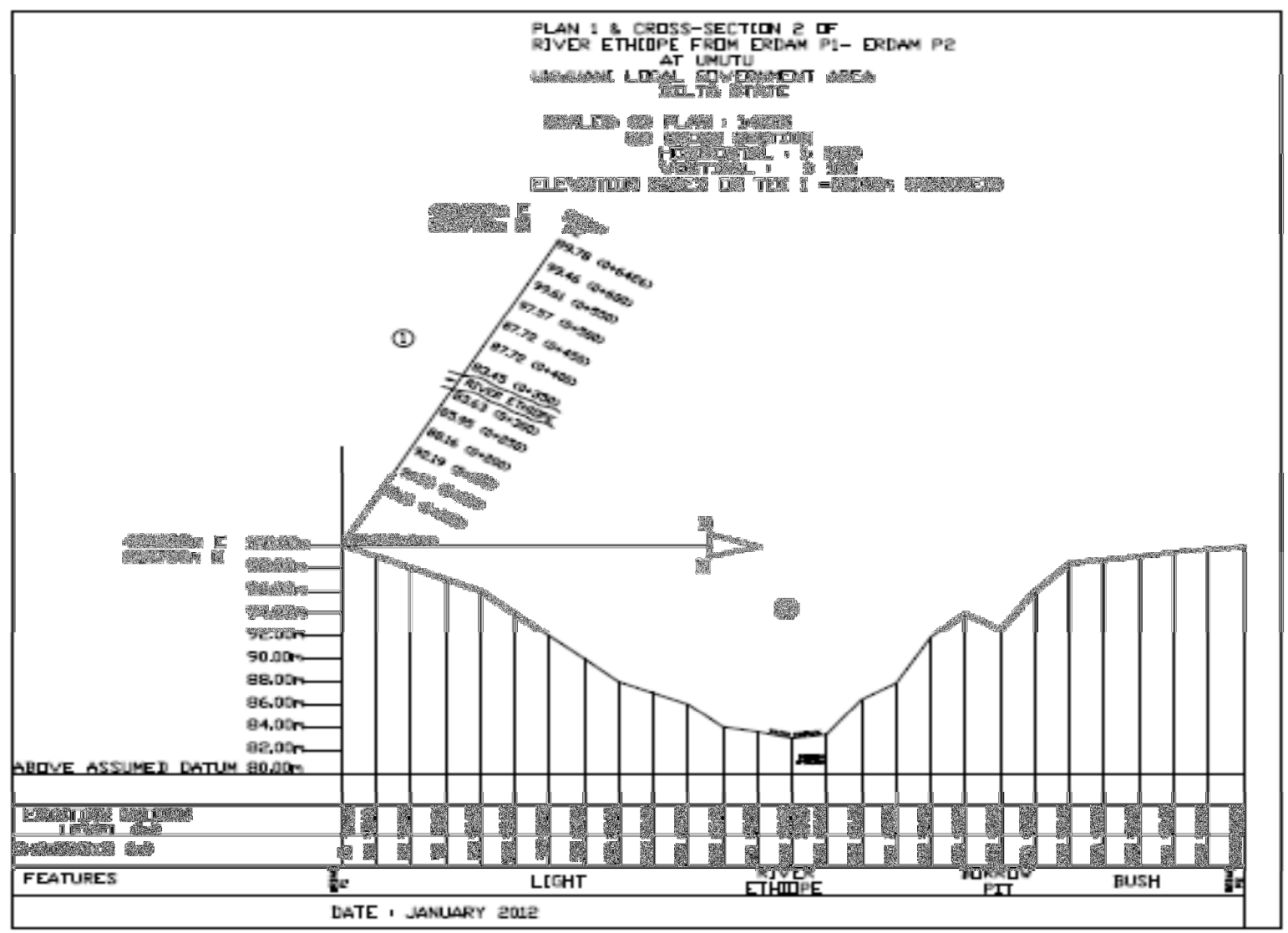

Figure 4 The Lake Profile

The site's annual temperature cycles were evaluated using data from Table 3. According to this data, the annual average temperature is around $30^{\circ} \mathrm{C}$.

Referring to Table 2, the kinematic viscosity of water at this ambient temperature is $0.801 \times 10^{-6} \mathrm{~m}^{2} / \mathrm{s}$. This coefficient is used to calculate the Reynolds' number as it is in equation (1).

$$
\begin{aligned}
R_{e}=\frac{\rho V D}{\mu}=\frac{V D}{\gamma} & =\frac{(27.179 \mathrm{~m} / \mathrm{s})(1.2192 \mathrm{~m})}{0.801 \times 10^{-6} \mathrm{~m}^{2} / \mathrm{s}} \\
& =41.37 \times 10^{6}
\end{aligned}
$$

The high Reynolds's number indicates that our fluid will exhibit a turbulent flow. This is a typical result as most engineering air and water pipe flows are turbulent not laminar [7]. 
It is only in ideal systems where hundred per cent of fluid's potential energy is translated to kinetic energy by hydraulic structures without inherent energy losses. But ideal systems only exist in mathematical models and do not provide an accurate portrayal of a real model. The designer of a hydroelectric power system must therefore account for head losses in the penstock when determining the actual amount of electric power available from the water resource.

Frictional losses associated with the penstock used for diverting the water from the in-take to the turbine accounts for the head losses in hydropower systems. There is friction between the fluid's outer layers and the inner surface of the penstock and this reduces the amount of energy converted from potential to kinetic energy. The material properties of the penstock coupled with fluid velocity and impending trajectory of the fluid flowing in the pipe determines the amount of losses due to friction. In every action, there is an equal and opposite reaction according to Newton's law of motion. Hence, if the fluid velocity increases, there will be a greater reaction leading to higher friction losses irrespective of the material properties of the penstock. The equation that follows accounts for system energy losses for non-ideal systems [6].

$$
\left(h_{1}+\frac{P_{1}}{\rho g}+\frac{V_{1}^{2}}{2 g}\right)=\left(h_{2}+\frac{P_{2}}{\rho g}+\frac{V_{2}^{2}}{2 g}\right)+h_{f}
$$

Where,

$\mathrm{h}_{1}$ is the elevation of the point above a reference plane (in the positive z-direction) (m), $\mathrm{P}_{1}$ is the pressure at that point $\left(\mathrm{Kg} / \mathrm{m}-\mathrm{s}^{2}\right), \rho$ is the density of the fluid at all points throughout the fluid $\left(\mathrm{Kg} / \mathrm{m}^{3}\right), \mathrm{g}$ is the gravitational acceleration $\left(\mathrm{m} / \mathrm{s}^{2}\right), \rho g$ is the specific weight of water $\left(\mathrm{Kg} / \mathrm{m}^{2}-\mathrm{s}^{2}\right), \mathrm{V}_{1}$ is the fluid flow rate at a point on the streamline $(\mathrm{m} / \mathrm{s})$

The head loss in pipes due to friction $=\mathrm{h}_{\mathrm{f}}$ and it can be expressed as:

$$
h_{f}=f \cdot \frac{L}{D} \cdot \frac{V^{2}}{2 g}
$$

This is known as Darcy-Weisbach energy loss equation (general form).

where,

$\mathrm{f}$ is the friction factor (unit-less), $\mathrm{L}$ is the length of the pipe $(\mathrm{m}), \mathrm{D}$ is the internal pipe diameter $(\mathrm{m}), \mathrm{V}$ is the average fluid velocity $(\mathrm{m} / \mathrm{s}), \mathrm{g}$ is the gravitational acceleration $\left(\mathrm{m}^{2} / \mathrm{s}\right)$

The equation (3) applies to systems with incompressible fluids exhibiting a steady flow rate through a closed circular pipe of any cross-section and it is valid for both turbulent and laminar flows.

Similarly, another equation known as the HagenPoiseville equation was developed to compute $h_{f}$ under laminar flow conditions only, namely,

$$
h_{f}=\frac{32 \mu L V}{\gamma D^{2}}
$$

Table 2. Dynamic and Kinematic Viscosity of Water [7].

\begin{tabular}{ccc}
\hline $\begin{array}{c}\text { Temperature, } \mathrm{t} \\
\left({ }^{\circ} \mathrm{C}\right)\end{array}$ & $\begin{array}{c}\text { Dynamic Viscosity, } \mu \\
(\mathrm{kg} /(\mathrm{m} . \mathrm{s})) \times 10^{-3}\end{array}$ & $\begin{array}{c}\text { Kinematic Viscosity, } \mathbf{v} \\
\left(\mathrm{m}^{2} / \mathrm{s}\right) \times 10^{-6}\end{array}$ \\
\hline 0 & 1.787 & 1.787 \\
5 & 1.519 & 1.519 \\
10 & 1.307 & 1.307 \\
20 & 1.002 & 1.004 \\
30 & 0.798 & 0.801 \\
40 & 0.653 & 0.658 \\
50 & 0.547 & 0.553 \\
60 & 0.467 & 0.475 \\
70 & 0.404 & 0.413 \\
80 & 0.355 & 0.365 \\
90 & 0.315 & 0.326 \\
100 & 0.282 & 0.294 \\
\hline
\end{tabular}

Table 3. Meteorological Observation Records of Temperature, 2008 - 2013, Yearly average $\left({ }^{\circ} \mathrm{C}\right)$ [8]. At Delsu Weather Station, Abraka

\begin{tabular}{|l|l|l|l|l|l|l|}
\hline Year & 2008 & 2009 & 2010 & 2011 & 2012 & 2013 \\
\hline Temperature & 30.2 & 30.0 & 30.2 & 31.1 & 31.0 & 28.3 \\
\hline
\end{tabular}

If we equate Darcy-Weisbach equation and HagenPoiseville equation, then we can find the friction factor, $\mathrm{f}$.

$$
f=\frac{64 \mu}{V D \rho}=\frac{64}{R_{e}}
$$

Thus the friction factor is a function of Reynolds's number and independent of the penstock's material properties as implied by the equation (5). In laminar flow, according to the equation (5), the friction factor is inversely proportional to viscous energy losses. Hence the system's head losses can be calculated by inserting the friction factor, $\mathrm{f}$, into the Darcy-Weisbach equation defined in equation (6) [6].

$$
h_{\text {floss }}=f \cdot \frac{L}{D} \cdot \frac{V^{2}}{2 g}=\frac{64 \mu}{\rho V D} \cdot \frac{L}{D} \cdot \frac{V^{2}}{2 g}=\frac{32 \mu L V}{\rho g D^{2}}
$$

The system's head losses are proportional to the fluid's average velocity $\mathrm{V}$ and this is in accordance with Newton's fundamental kinematic principles, which states that an increase in the fluid's impending velocity on the penstock's interior surface will result in an increase in friction losses.

The friction factor $\mathrm{f}$ for penstock employing smooth interior surface can be approximated using the following equation for fluids exhibiting turbulent flow [6].

$$
\frac{1}{\sqrt{f}}=2.0 \log \left(R_{e} \sqrt{f}\right)-0.8
$$

The friction factor, $\mathrm{f}$, can also be approximated using the alternative equation defined as [6].

$f=0.316 R_{e}^{-1 / 4}$. for $4000 .<. R_{e} \cdot<.10^{5}$

and

$f=\left(1.8 \log \frac{R_{e}}{6.9}\right)^{-2}$ else where

The Reynolds's number $\mathrm{R}_{\mathrm{e}}$ for this particular system on River Ethiope was calculated to be $41.37 \times 10^{6}$. Thus observing the defined boundaries for the 
equations (7) and (9), the latter equation can be applied to approximate the friction factor $\mathrm{f}$ for this system where the fluid is in turbulent flow.

The friction factor $\mathrm{f}$ is calculated below.

$$
f=\left(\log \frac{41.37 \times 10^{6}}{6.9}\right)^{-2}=0.00672
$$

The Darcy-Weisbach equation is then evaluated by inserting the value of friction factor and applying a pipe diameter of 1.219 metres, a total penstock length $\mathrm{L}$ of 45 meters, and an average velocity $\mathrm{V}$ of 27.179 $\mathrm{m} / \mathrm{s}$.

$$
\begin{gathered}
h_{f t u r b}=f \times \frac{L}{D} \times \frac{V^{2}}{2 g} \times \frac{45}{1.219} \times \frac{27.179^{2}}{2 \times 9.81} \times 0.00672 \\
=9.3 \mathrm{~m}
\end{gathered}
$$

The head loss inherent in this system is $9.3 \mathrm{~m}$. Head loss refers to the loss of water power due to friction within the pipeline or penstock. Although a given pipe diameter may be sufficient to carry all of the design flow, the sides, joints, and bends of the pipe create drag as the water passes by, slowing it down. The effect is the same as lowering the head - less water pressure at the turbine. The head losses are used to calculate the system's net head.

$$
H_{\text {net }}=H_{\text {gross }}-h_{f}=18.5-9.3=9.2 \mathrm{~m}
$$

\subsection{Calculating Hydropower Potential of River Ethiope}

As noted earlier, the two most important parameters that are used to determine the power output of any water resource are the flow and the head. Conceptually, the equation generally used to determine the power output based on the flow and head is [9].

$$
P=n \rho g Q H
$$

Where $P$ is Power (watts), $\eta$ is overall efficiency (\%), $\rho$ is the density of water $\left(1000 \mathrm{~kg} / \mathrm{m}^{3}\right), \mathrm{g}$ is the acceleration due to gravity $\left(9.81 \mathrm{~m} / \mathrm{s}^{2}\right), \mathrm{Q}$ is the water flow rate $\left(\mathrm{m}^{3} / \mathrm{s}\right)$ and $\mathrm{H}$ is the net head $(\mathrm{m})$.

The flow of the River Ethiope was measured to be $31.73 \mathrm{~m}^{3} / \mathrm{s}$ [4] and a head of $9.2 \mathrm{~m}$ as calculated from the losses with an assumed efficiency of 0.85 will be used to estimate the power output from the river. That is:

$\mathrm{P}=0.85 \times 1000 \times 9.81 \times 31.73 \times 9.2=2,434,141.566$ $\mathrm{kW} .=2.43 \mathrm{MW}$.

The available power from the River Ethiope using a flow rate of $31.73 \mathrm{~m}^{3} / \mathrm{s}$ and a net head of $9.2 \mathrm{~m}$ is 2.43 MW. This power can go a long way in solving part of the power need of the Delta State University Abraka and the host communities.

\section{CONCLUSIONS}

The purpose of the study was to determine appropriate head for the River Ethiope. Dumpy levels and Theodolite method were employed. From the results of the measurement, a profile of the river was drawn and $18.5 \mathrm{~m}$ head was estimated. However, due to losses orchestrated by friction between the water and the penstock a head loss of $9.3 \mathrm{~m}$ was calculated. Based on this head, the power output of $2.43 \mathrm{MW}$ was also deduced. This study shows that River Ethiope has potential for small hydropower development. Small hydropower is sustainable and renewable energy source. Small hydropower is a well-developed small scale renewable energy technology, which can contribute to the improvement of electricity supply in rural areas.

\section{REFERENCES}

1. U.S.A Department of Energy, (2001). Small Hydropower Systems. DOE/GO-102001-1173 FS 217.

2. Micro-Hydropower System (2006). "A Buyers Guide". Natural Resources Canada Ontario.

3. Akpoborie I A (2012). Time Series Analysis of Stream-flow Variability in the Ethiope and Adofi Rivers, Delta State Nigeria. In Akpotor A S et al. (Eds). Five Decades of Oil Production in Nigeria: Impact on the Niger Delta. CENDS, Abraka, pp 275 290.

4. Otuagoma S O; Ogujor E A; Kuale P A (2015). Comparative Measurement of Stream Flow in the Ethiope River for Small Hydropower Development. Nigerian Journal of Technology Vol 34, No 1, pp 184 - 192.

5. Adiotomre E A; Adaikpoh E O and Erhisere O (1999). The Gravel Packing Properties of Sand Deposit in the Ethiope River Catchment. Geo Research, 421 - 26.

6. White F M (1999). University of Rhode Island. Fluid Mechanics, $4^{\text {th }}$ Edition, McGraw Hill Series in Mechanical Engineering, pp 1-960.

7. Brown T M (2010). Hydroelectric System Design. A Thesis Presented to the Faculty of California Polytechnic State University, San Luis Obispo, pp 1 93.

8. Meteorological Year Book (2008 - 2013). Meteorological Weather Station, Geography Department, Delta State University, Abraka.

9. Sule B F; Salami A W; Bilewu S O; Adeleke O O and Ajimotokan H A (2011). Hydrology of River Oyun and Hydropower Potential of Unilorin Dam, Ilorin Kwara State, Nigeria. New York Science Journal, 4 (1) $69-78$. 